\title{
Barriers in Adoption of Building Information Modeling in Pakistan's Construction Industry
}

\author{
Fida Siddiqui', Muhammad Akram Akhund ${ }^{1 *}$, Tauha Hussain Ali ${ }^{1}$, Shabeer Hussain Khahro², \\ Ali Raza Khoso ${ }^{1}$ and Hafiz Usama Imad ${ }^{3}$
}

\author{
'Department of Civil Engineering, Mehran University of Engineering and Technology, Jamshoro, Pakistan; \\ fida.siddiqui@faculty.muet.edu.pk, akhund42@gmail.com, sacharvi2@gmail.com, aliraza.khoso@faculty.muet.edu.pk \\ 2Department of Engineering Management, Prince Sultan University, Riyadh, Saudi Arabia; shkhahro@gmail.com \\ 32Department of Civil Engineering, ISRA University, Hyderabad, Pakistan; usamaimad@yahoo.com
}

\begin{abstract}
Building Information Modelling (BIM) is ubiquitous and one of the finest approaches in the construction industry of developing country such as Pakistan's. But implementation in the mentioned country's industry has been slow and numerous hindrances have been faced by the construction practitioners up till now. Objectives: This study aims to highlight barriers in adoption of building information modelling in Pakistan's construction industry. Methods: Current research survey was undertaken in the entire country after a pilot study. Findings: The study revealing the barriers in adoption of BIM. Lack of Skilled personnel, Unwillingness to share Information between Stakeholders, Legal and Security Issues, High Cost of Implementation were the few important factors revealed. Though, the results vary due to the development level difference in every country. Application/ Improvements: Thus, this article adds in the literature the hindrances/barriers faced by the concerned industry and their significance level.
\end{abstract}

Keywords: Barriers, Building Information Modelling (BIM), Construction Projects

\section{Introduction}

Building Information Modeling (BIM) has transformed the infrastructure development within the civil engineering industry over the previous decade ${ }^{1}$. BIM has proved to be beneficial for improving the quality of project and reducing cost, time, and human resources. BIM increases the collaboration between the Architects, Structural Engineers, MEP contractors and Construction Managers $\frac{2,3}{}$.

BIM can be defined as a multi-dimensional and virtual representation of the physical and functional characteristics of the project to be built. It serves as a shared knowledge resource for information to aid in decisionmaking during conceptual and design phase, construction planning and scheduling, cost estimates and maintenance of construction projects etc ${ }^{4}$.
BIM provides better insight of the project for the cost, schedule and constructability ${ }^{5}$. It improves building quality, reduces lifecycle costs, reduces reworking, improves safety, enables the owner to better understand the projects from the beginning to end, and optimizes the operational efficiency ${ }^{6}$. A shared knowledge resource is created by the implementation of BIM which contains important design and operational information about the project. BIM makes use of the actual engineering data for creating the $\mathrm{nD}$ models and helps in identifying and reducing the errors and conflicts even before the start of the construction on ground.

The Construction Industry (CI) has been less productive as compared to other industries in the past 50 years and there are various factors which contribute to this ${ }^{7}$. Most important of those factors is "improper management of the projects" which includes impractical

${ }^{*}$ Author for correspondence 
scheduling and planning, inability to detect conflicts at the beginning, poor or inaccurate estimation of the quantities and cost of project, reworking, lack of collaboration and communication between different stakeholders etc. All these factors affect the quality of project and increases cost and time of the project which eventually results in decreased productivity of the CI.

Various software programs are developed to counter these factors which are affecting the productivity of the CI. BIM is a technique that is utilized by those software programs. BIM is very useful tool for the clash detection, scheduling, fast and accurate time and cost estimation, quantification, visualization of the project through $3 \mathrm{D}$ models, and enhancing collaboration among all the stakeholders thus resulting in better productivity ${ }^{\underline{8}}$.

There are several claims in the past researches that BIM helps in the reduction of cost, time and improves quality. It has also been observed that there are various barriers in the BIM implementation, thus significance of this study is that it will enable us to analyze whether the claims are true for the CI of Pakistan or not and to determine what are the barriers for BIM in Pakistan.

BIM's increased utilization in the industry has fueled a greater interest for research and studies regarding its level of market infiltration and benefits in building construction.

A number of problems are encountered during the implementation of BIM in the $\mathrm{CI}$ and this is due to various barriers that cause hindrances in the effective adoption of BIM. The slow BIM implementation is simply not due to one single issue, but rather it is due to the combination of various issues. To implement BIM effectively in the CI, all these issues must be resolved? .

Several authors have identified barriers in the implementation of BIM. According to ${ }^{10,11}$ barriers of BIM include Lack of skilled personnel, High cost of implementation, Lack of National Standard, Legal issues, Distribution of risks and costs and project manager needs knowledge of BIM to succeed $\frac{12}{2}$, further identified reluctance to introduce new technology, Organizational issues, Lack of interest of government and increase in the cost of human resource due to lack of professionals also cause hindrance in the BIM adoption.

There are many other researchers who have done extensive research on the causes of slow adoption of BIM and recognized several factors. According to ${ }^{\frac{13}{3}}$, BIM wastes time and cost, there is lack of case study as an evidence of financial benefit, Unsuitability for project and people refusal to learn. According to ${ }^{\frac{14}{4}}$, barriers include Lack of demand from client, Lack of I.T infrastructure; Initial setup of BIM is difficult. According to ${ }^{10}$, Productivity losses during transition period and the software programs are complex to use, are the barriers of BIM. Mapping of all these barriers is done in Table 1 .

Table 1. Test model specifications and test conditions

\begin{tabular}{|c|c|}
\hline No. & BIM Barrier \\
\hline 01 & $\begin{array}{l}\text { High cost of implementation (Training, Education } \\
\text { and Software) }\end{array}$ \\
\hline 02 & $\begin{array}{l}\text { Lack of Skilled personnel/Lack of adequately trained } \\
\text { BIM professionals. }\end{array}$ \\
\hline 03 & $\begin{array}{l}\text { Interoperability or Unwillingness to share } \\
\text { Information between Stakeholders/ Lack of } \\
\text { information sharing. }\end{array}$ \\
\hline 04 & $\begin{array}{l}\text { Legal and Security Issues/ Security of confidential } \\
\text { data in BIM model/Ownership, Insurance and } \\
\text { Licensing. }\end{array}$ \\
\hline 05 & Lack of National Standard \\
\hline 06 & $\begin{array}{l}\text { Reluctant to introduce new technology due to social } \\
\text { and habitual resistance to change (Satisfied with } \\
\text { traditional Methods) }\end{array}$ \\
\hline 07 & Organizational issues (Not ready for change) \\
\hline 08 & Lack of demand from client. \\
\hline 09 & Lack of interest of Government. \\
\hline 10 & $\begin{array}{l}\text { Who should take responsibility for which parts of } \\
\text { model (Distribution of risks and costs) }\end{array}$ \\
\hline 11 & $\begin{array}{l}\text { Lack of case study as an evidence of financial benefit } \\
\text { of BIM. }\end{array}$ \\
\hline 12 & $\begin{array}{l}\text { Productivity losses during transition period from } \\
\text { traditional methods to BIM. }\end{array}$ \\
\hline 13 & $\begin{array}{l}\text { The software programs are complex and are not easy } \\
\text { to use. }\end{array}$ \\
\hline 14 & Wastes time and human resource. \\
\hline 15 & $\begin{array}{l}\text { Project manager needs knowledge and experience of } \\
\text { BIM to succeed. }\end{array}$ \\
\hline 16 & $\begin{array}{l}\text { Increases cost of Human Resource (Due to lack of } \\
\text { professionals) }\end{array}$ \\
\hline 17 & Lack of IT Infrastructure. \\
\hline 18 & Initial Setup of BIM is difficult. \\
\hline 19 & People refuse to learn \\
\hline 20 & Unsuitable for the project. \\
\hline 21 & Reluctance to co-operate with other professionals. \\
\hline
\end{tabular}

\section{Research Methodology}

Current study adopts initially a literature review to spot the barriers in implementation of BIM. Moreover, a 
structured questionnaire was circulated amongst professionals to investigate their perceptions concerning the implementation of BIM. Pakistan Engineering Council's database was utilized to search the construction professionals; served as a sample for this research.

Structured questionnaire prepared and used for the collection of data, was distributed to a total of 120 people, among which 89 responses were obtained leading to the response rate of $75 \%$, which is quite satisfactory as per recommendations ${ }^{20,21}$. Random sampling technique was used as surveying methodology. In this technique, every member of population has equal and likely chances to be involved as respondent leading to a known and nonzero probability of selection. It is recommended to use this method due to cost efficiency, quicker response and increased reliability of data.

The questionnaire contained two main sections. The first section pursued information on the respondents' profile i.e., demographic variables. The second section sought about the ranking of barriers in implementation of BIM in construction projects of Pakistan. 5-point Likert scale was used, and the data was analyzed using descriptive statistics and average index method ${ }^{22}$.

\section{Result and Discussion}

Figure 1 show that $61 \%$ of the survey participants were members of the consultant firms, $11 \%$ were member of constructor firms and 9\% survey participants from client sector. While $19 \%$ of survey respondents participants except from consultant, constructor and client firms, but are registered under the license of Pakistan Engineering Council.

In continuation to that, the respondents involved in this study had vast range of experiences. The results depict that more than $58 \%$ respondents had experience of more than 11 years of working with BIM applications. About
$18 \%$ respondents had experience of 6 to 10 years of working in construction industry in which BIM applications are used. More than $30 \%$ respondents had experience of 5 years or less. As data shows a variety of experience range, which portrays opinion of stakeholders of all categories leading towards high reliability.

Similarly, there are three categories of organizations involved in this survey. Most of the respondents are from the private sector with 72 respondents. This is followed by government sector with 13 respondents. Organization of joint venture category is the lowest with 4 respondents. Table 2 presents the results of respondent's experience and its category of organization.

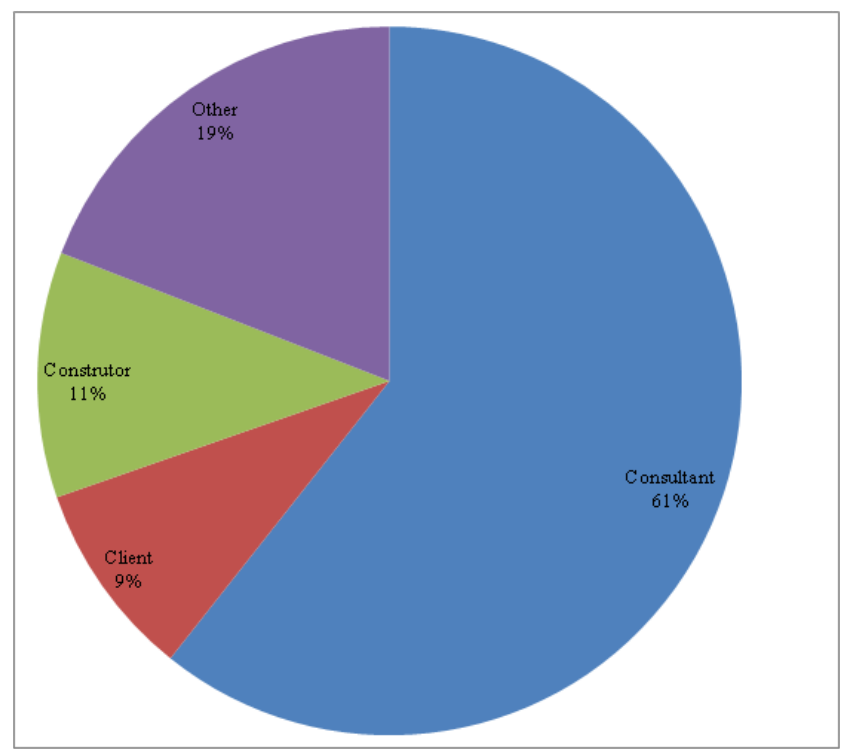

Figure 1. Type of survey participants.

The study identifies the main critical barrier to the implementation of BIM to the construction industry. Table 3 shows the relative rank among the critical factors that affect the successful implementation of BIM technology in construction industry based on the existing frequency of descriptive data collection materials.

Table 2. Experience respondents and its category of organization

\begin{tabular}{|l|l|l|l|l|l|}
\hline $\begin{array}{l}\text { Respondents } \\
\text { Experience }\end{array}$ & Frequency & Percentage & $\begin{array}{l}\text { Category of } \\
\text { Organization }\end{array}$ & Frequency & Percentage \\
\hline $\begin{array}{l}\text { More than } 11 \\
\text { Years }\end{array}$ & 46 & 51.68 & Private & 72 & 80.89 \\
\hline $6-10$ Years & 16 & 17.97 & Government & 13 & 14.61 \\
\hline $\begin{array}{l}\text { Less than } 5 \\
\text { Years }\end{array}$ & 27 & 30.33 & Joint Venture & 4 & 4.49 \\
\hline Total & $\mathbf{8 9}$ & 100 & Total & 89 & 100 \\
\hline
\end{tabular}


Table 3. Barriers in implementation BIM

\begin{tabular}{|c|c|c|c|c|c|c|c|c|c|}
\hline No. & BIM Barrier & ES & VS & MS & SS & NS & SD & AI & Rank \\
\hline $\mathrm{BB}_{1}$ & $\begin{array}{l}\text { High cost of implementation (Training, Education and } \\
\text { Software) }\end{array}$ & 40 & 22 & 15 & 5 & 7 & 0.98 & 3.93 & 4 \\
\hline $\mathrm{BB}_{2}$ & $\begin{array}{l}\text { Lack of Skilled personnel/Lack of adequately trained } \\
\text { BIM professionals. }\end{array}$ & 53 & 13 & 11 & 6 & 6 & 1.05 & 4.13 & 1 \\
\hline $\mathrm{BB}_{3}$ & $\begin{array}{l}\text { Interoperability/Unwillingness to share Information } \\
\text { between Stakeholders/ Lack of information sharing. }\end{array}$ & 47 & 22 & 6 & 9 & 5 & 1.03 & 4.09 & 2 \\
\hline $\mathrm{BB}_{4}$ & $\begin{array}{l}\text { Legal and Security Issues/ Security of confidential data } \\
\text { in BIM model/Ownership, Insurance and Licensing. }\end{array}$ & 56 & 9 & 6 & 11 & 7 & 1.02 & 4.08 & 3 \\
\hline $\mathrm{BB}_{5}$ & Lack of National Standard & 38 & 13 & 22 & 10 & 6 & 0.95 & 3.75 & 8 \\
\hline $\mathrm{BB}_{6}$ & $\begin{array}{l}\text { Reluctant to introduce new technology due to social } \\
\text { and habitual resistance to change (Satisfied with } \\
\text { traditional Methods) }\end{array}$ & 42 & 18 & 9 & 14 & 6 & 0.97 & 3.85 & 6 \\
\hline $\mathrm{BB}_{7}$ & Organizational issues (Not ready for change) & 38 & 22 & 11 & 9 & 9 & 0.96 & 3.80 & 7 \\
\hline $\mathrm{BB}_{8}$ & Lack of demand from client. & 46 & 16 & 6 & 12 & 9 & 0.97 & 3.88 & 5 \\
\hline $\mathrm{BB}_{9}$ & Lack of interest of Government. & 32 & 22 & 14 & 16 & 5 & 0.94 & 3.67 & 9 \\
\hline $\mathrm{BB}_{10}$ & $\begin{array}{l}\text { Who should take responsibility for which parts of } \\
\text { model (Distribution of risks and costs) }\end{array}$ & 26 & 16 & 8 & 19 & 20 & 0.86 & 3.10 & 16 \\
\hline $\mathrm{BB}_{11}$ & $\begin{array}{l}\text { Lack of case study as an evidence of financial benefit of } \\
\text { BIM. }\end{array}$ & 36 & 12 & 9 & 18 & 14 & 0.91 & 3.43 & 12 \\
\hline $\mathrm{BB}_{12}$ & $\begin{array}{l}\text { Productivity losses during transition period from } \\
\text { traditional methods to BIM. }\end{array}$ & 24 & 28 & 11 & 9 & 17 & 0.90 & 3.37 & 13 \\
\hline $\mathrm{BB}_{13}$ & $\begin{array}{l}\text { The software programs are complex and are not easy to } \\
\text { use. }\end{array}$ & 24 & 12 & 26 & 16 & 11 & 0.88 & 3.25 & 15 \\
\hline $\mathrm{BB}_{14}$ & Wastes time and human resource. & 24 & 18 & 32 & 9 & 6 & 0.92 & 3.51 & 11 \\
\hline $\mathrm{BB}_{15}$ & $\begin{array}{l}\text { Project manager needs knowledge and experience of } \\
\text { BIM to succeed. }\end{array}$ & 28 & 16 & 20 & 11 & 14 & 0.90 & 3.37 & 13 \\
\hline $\mathrm{BB}_{16}$ & $\begin{array}{l}\text { Increases cost of Human Resource (Due to lack of } \\
\text { professionals) }\end{array}$ & 38 & 9 & 14 & 19 & 9 & 0.92 & 3.54 & 10 \\
\hline $\mathrm{BB}_{17}$ & Lack of IT Infrastructure. & 26 & 8 & 32 & 14 & 9 & 0.89 & 3.31 & 14 \\
\hline $\mathrm{BB}_{18}$ & Initial Setup of BIM is difficult. & 12 & 22 & 16 & 22 & 17 & 0.86 & 2.89 & 17 \\
\hline $\mathrm{BB}_{19}$ & People refuse to learn & 11 & 20 & 32 & 19 & 7 & 0.86 & 3.10 & 16 \\
\hline $\mathrm{BB}_{20}$ & Unsuitable for the project. & 19 & 8 & 22 & 21 & 19 & 0.87 & 2.85 & 18 \\
\hline $\mathrm{BB}_{21}$ & Reluctance to co-operate with other professionals. & 40 & 22 & 15 & 5 & 7 & 0.98 & 3.93 & 4 \\
\hline
\end{tabular}

Table shows 3, shows that the barrier "Lack of Skilled Personnel" is ranked first with an AI of 4.13 and SD of 1.05 , followed by "Interoperability" with an AI of 4.09 and SD of 1.04. "Legal and Security Issues" comes at third rank with an AI of 4.08. Fourth most important barrier highlighted through the survey is "High cost of implementation" with an AI of 3.73 and value of SD as 0.98 .

\subsection{Lack of Skilled Personnel}

The lack of skilled or well-trained BIM professionals is one of the biggest barriers in the implementation of BIM in the construction industry since productivity of BIM is completely dependent on the qualification of the person using the BIM tool. For the successful implementation of BIM, the project team members must be skilled in their respective specific field regarding BIM.

According to the study by ${ }^{13}$, majority of the companies in their research who had not adopted BIM believed that the process of training would cost a lot of money with respect to time and human resource. Furthermore they considered the issue of training to be the largest barrier to BIM implementation because of the investment following 
the change. Decisions are generally made by the investors on the basis of financial gains but due to insufficient number of case-studies and lack of evidence for potential financial benefit of BIM the companies are generally not very keen in investing.

A wide range of BIM short courses are offered in the market. However, the quality of these courses varies considerably due to lack of clear BIM guidelines by the government. Even for the diploma and undergraduate degree programs offered by the local universities, requirement of BIM training in their curricula is neither standardized nor mandatory. This is the reason why the respondents demand more "proper" education and training for $\mathrm{BIM}^{15}$.

\subsection{Interoperability}

As construction projects requires a sophisticated exchange of reliable information among all the stakeholders, which makes this process a complex process. Conventionally all this information was shared in shape of document and drawings, but this was not effective. Due to adoption of BIM, a decent piece of information can be exchanged in an effective manner. This tool is not only valuable at design phase, but it also helps in information interchange amongst various people at different phases.

There might be a different approach of each construction practitioner who uses different tool or had links with several vendors. This makes the record keeping and information management more difficult. Designed BIM tool also varies from place to place and project to project due to variation of vendor, or different nature of business for each user. This is still a challenge for BIM users which is due to inadequate or lack of interoperability. Interoperability in BIM for use in multivariate projects and for multi-accurate models for the accomplishment of several purposes within a single model is still a challenge for developers 9 .

\subsection{Legal and Security Issues}

Implementation of BIM has barrier of several legal aspects. One of the most important aspects is ownership of the data. There is always a conflict of interest among the owner and developer, but sometimes the claims are also made by architects and designers. There is no universal solution to this problem but can be managed by case to case and project to project depending on circumstances of each project. The second most occurring legal issue in
BIM is licensing problem and this problem exaggerates when data is entered by multiple users of different fields ${ }^{6}$. Another important problem in this field is the position of rights of accessing and controlling the data. As every partner claims to possess access and rights to keep, modify and control the data. In case of multiple accesses, the issue of inconsistency, inaccuracy, and irregularity of data may happen, and no one will be ready to take responsibility of that ${ }^{12}$.

Another major problem in BIM modeling is inaccuracies in the data, which leads to faulty calculations and inaccurate predictions. The process of data entry and data updating entails a large risk factor and ensuring data accuracy had always been a challenge to the professionals. Though BIM models can run a huge data with speed and accuracy and gives cost and time estimates in a reliable manner, but it needs proper and precise data entry. Besides the dimension of reliable estimations and persistent schedules of cost and time the issue of interoperability between various users and amid parts of the model is of concern. This issue also occurs when data from various BIM tools is linked together and a single run has been made. This issue needs re-entering and update of the data as per dimensions of new tool being used ${ }^{9}$.

\subsection{High cost of Implementation}

It is expected that BIM will provide significant benefits to the AEC industry but its adoption and implementation requires costs, as with any new technology. The perceived costs for the implementation of BIM technology consists of education and training costs, administrative and start-up costs, and costs during the transitional period. Implementation cost is commonly considered as a barrier to the BIM implementation. Implementation of BIM has mainly increased in the large companies which have the resources. Specific software and data storage is required for BIM implementation which costs a significant amount of money to the company. New software's cost depends on the firm's existing IT facility but that cost could present a barrier to small firms. High cost of implementation and applications forces investors and potential BIM adopters to consider their options carefully ${ }^{16-19}$.

\section{Conclusion}

BIM is one of the advanced and utmost requirements of the era for the construction industry specifically, for 
Pakistan. BIM is helpful in detecting the clashes amongst various models of any construction project prior to real execution. Thus, helps in saving cost, time, design and execution complexities. Numerous obstructions are observed in a construction industry like Pakistan's in implementing BIM such as Lack of Skilled Personnel, Legal and Security Issues, High cost of implementation etc. The higher officials will have to take serious actions including training of personnel, arranging awareness and information workshops and seminars for proper intrusion of BIM in the industry. Though the initial setup is difficult and costly but once implemented, the organizations will groom and industry will flourish well.

\section{References}

1. Antwi-Afari MF, Li H, Pärn EA, Edwards DJ. Critical success factors for implementing Building Information Modelling (BIM): A longitudinal review, Automation in Construction. 2018; 91:100-10. https://doi.org/10.1016/j. autcon.2018.03.010.

2. Liu Y, Van Nederveen S, Hertogh M. Understanding effects of BIM on collaborative design and construction: An empirical study in China, International Journal of Project Management. 2017; 35(4):686-98. https://doi. org/10.1016/j.ijproman.2016.06.007.

3. Matarneh R, Hamed S. Barriers to the adoption of Building Information Modeling (BIM) in the Jordanian Building Industry, Open Journal of Civil Engineering. 2017; 7(03):325. https://doi.org/10.4236/ojce.2017.73022.

4. BIM handbook: A guide to building information modeling for owners, managers, designers, engineers and contractors. Date accessed: 03/03/2008. https://books.google.co.in/books/about/BIM_Handbook. html?id=IioygN0nYzMC\&redir_esc=y.

5. Migilinskas D, Popov V, Juocevicius V, Ustinovichius L. The benefits, obstacles and problems of practical BIM implementation, Procedia Engineering. 2013; 57:767-74. https:// doi.org/10.1016/j.proeng.2013.04.097.

6. Ahn YH, Kwak YH, Suk SJ. Contractors' transformation strategies for adopting building information modeling, Journal of Management in Engineering. 2015; 32(1). https://doi.org/10.1061/(ASCE)ME.1943-5479.0000390.

7. Arayici Y, Egbu CO, Coates SP. Building Information Modelling (BIM) implementation and remote construction projects: Issues, challenges, and critiques, Journal of Information Technology in Construction. 2012; 17:75-92.

8. Wang H, Zhai ZJ. Advances in building simulation and computational techniques: A review between 1987 and
2014, Energy and Buildings. 2016; 128:319-35. https://doi. org/10.1016/j.enbuild.2016.06.080.

9. Lindblad H. Study of the implementation process of BIM in construction projects. Thesis of Master of Science, Department of Real Estate and Construction Management, Architecture and Build Environment, 2013. p. 1-65.

10. Azhar S. Building Information Modeling (BIM): Trends, benefits, risks, and challenges for the AEC industry, Leadership and Management in Engineering. 2011; 11(3):241-52. https://doi.org/10.1061/(ASCE)LM.19435630.0000127.

11. Rokooei S. Building Information Modeling (BIM) in project management: necessities, challenges and outcomes, Procedia-Social and Behavioral Sciences. 2015; 210:87-95. https://doi.org/10.1016/j.sbspro.2015.11.332.

12. Liu S, Xie B, Tivendal L, Liu C. Critical barriers to BIM implementation in the AEC industry. International Journal of Marketing Studies. 2015, 7(6), pp. 162. https://doi. org/10.5539/ijms.v7n6p162.

13. Yan $H$, Demain P. Benefits and barriers of Building Information Modelling (BIM). In: Ren, A., Ma, Z. and Lu, $\mathrm{X}$. Proceedings of the 12th International Conference on Computing in Civil and Building Engineering (ICCCBE $\mathrm{XII}$ ) and International Conference on Information Technology in Construction, 2008. p. 1-6.

14. Chan CT. Barriers of implementing BIM in construction industry from the designers' perspective: A Hong Kong experience, Journal of System and Management Sciences. 2014; 4(2):24-40.

15. Kekana TG, Aigbavboa CO, Thwala WD. Building Information Modelling (BIM): Barriers in adoption and implementation strategies in the South Africa construction industry. In: International Conference on Emerging Trends in Computer and Image Processing, Pattaya, Thailand; 2014. p. 1-3.

16. Memon AH, Rahman IA, Memon I, Azman NIA. BIM in Malaysian construction industry: status, advantages, barriers and strategies to enhance the implementation level, Research Journal of Applied Sciences, Engineering and Technology. 2014; 8(5):606-14. https://doi.org/10.19026/rjaset.8.1012.

17. Palamar T. Mastering Autodesk Maya 2016: Autodesk Official Press. John Wiley \& Sons; 2015.

18. Oduyemi O, Okoroh MI, Fajana OS. The application and barriers of BIM in sustainable building design, Journal of Facilities Management. 2017; 15(1):15-34. https://doi. org/10.1108/JFM-03-2016-0008.

19. Olawumi TO, Chan DW, Wong JK, Chan AP. Barriers to the integration of BIM and sustainability practices in construction projects: A Delphi survey of international experts, 
Journal of Building Engineering. 2018; 20:60-71. https:// doi.org/10.1016/j.jobe.2018.06.017.

20. Dulaimi MF, Ling FY, Bajracharya A. Organizational motivation and inter-organizational interaction in construction innovation in Singapore. Construction Management and economics, 2003 ; 21(3): 307-318.
21. Akintoye A. Analysis of factors influencing project cost estimating practice. Construction Management \& Economics. 2000; 18(1): 77-89.

22. Imad HU, Akhund MA, Ali M, Pathan AA, Ahmed A. Non-Volumetric Pricing is a Threat to Water Reserves. Civil Engineering Journal. 2019 Feb 26;5(2):422-8. 